\title{
Comparison of one-catheter strategy versus conventional two-catheter strategy on the volume of radiological contrast and diagnostic coronary catheterization performance by transradial access: A systematic review and meta-analysis of randomized clinical trials
}

\section{Comparación de la estrategia de catéter único versus la estrategia convencional de dos catéteres sobre el volumen de contraste radiológico y el rendimiento del cateterismo coronario diagnóstico por acceso transradial: una revisión sistemática y meta-análisis de ensayos clínicos aleatorizados}

\author{
Diego Fernández-Rodríguez*, Joan Costa-Mateu, Kristian Rivera, Juan Casanova, Anna Bosch-Gaya, \\ Carlos Tomás-Querol, Marta Zielonka, Eduardo Pereyra-Acha, Lucía Matute-Blanco, and \\ Fernando Worner \\ Department of Cardiology, University Hospital Arnau de Vilanova, Institut de Recerca Biomédica de Lleida, University of Lleida, Lleida, Spain
}

\begin{abstract}
Background: One-catheter strategy, based in multipurpose catheters, allows exploring both coronary arteries with a single catheter. This strategy could simplify coronary catheterization and reduce the volume of contrast administration, by reducing radial spasm. To date, observational studies showed greater benefits regarding contrast consumption and catheterization performance than controlled trials. The aim of this work is to perform the first systematic review and meta-analysis of randomized clinical trials (RCT) to adequately quantify the benefits of one-catheter strategy, with multipurpose catheters, over conventional two-catheter strategy on contrast consumption, and catheterization performance. Methods: $A$ search in PubMed, CINALH, and CENTRAL databases was conducted to identify randomized trials comparing one-catheter and two-catheter strategies. The primary outcome was volume of iodinated contrast administrated. Secondary endpoints, evaluating coronary catheterization performance included: arterial spasm, fluoroscopy time, and procedural time. Results: Five RCT were included for the final analysis, with a total of 1599 patients (802 patients with one-catheter strategy and 797 patients with two-catheter strategy). One-catheter strategy required less administration of radiological contrast (difference in means [DiM] [95\% confidence interval (Cl)]; $-3.831 \mathrm{~mL}[-6.165 \mathrm{~mL}$ to $-1.496 \mathrm{~mL}], p=0.001$ ) as compared to two-catheter strategy. Furthermore, less radial spasm (odds ratio [95\% Cl], 0.484 [0.363 to 0.644], $p<0.001$ ) and less procedural time (DiM [95\% Cl], $-72.471 \mathrm{~s}$ [-99.694 $s$ to $-45.249 s], p<0.001)$ were observed in one-catheter strategy. No differences on fluoroscopy time were observed. Conclusions: One-catheter strategy induces a minimal reduction on radiological contrast administration but improves
\end{abstract}

Correspondence:

*Diego Fernández-Rodríguez

E-mail: d.fernan.2@ hotmail.com

1405-9940 DOl: 10.24875/ACM.19000352

1405-9940 / @ 2020 Instituto Nacional de Cardiología Ignacio Chávez. Published by Permanyer. This is an open access article under the CC BY-NC-ND license (http://creativecommons.org/licenses/by-nc-nd/4.0/).
Date of reception: 01-10-2019

Date of acceptance: $30-06-2020$ 
coronary catheterization performance by reducing arterial spasm and procedural time as compared to conventional two-catheter strategy.

Key words: Coronary angiography. One-catheter strategy. Radial spasm. lodinated contrast. Systematic review. Meta-analysis.

\section{Resumen}

Antecedentes: La estrategia de catéter único permite explorar ambas coronarias con un solo catéter. Nuestro objetivo es realizar la primera revisión sistemática y meta-análisis de ensayos clínicos aleatorizados para cuantificar adecuadamente los beneficios de la estrategia de catéter único, con catéteres multipropósito, sobre la estrategia convencional de dos catéteres. Métodos: Se realizó una búsqueda en PubMed, CINALH y CENTRAL, identificando ensayos aleatorizados que compararan estrategias de un catéter y dos catéteres. El resultado primario fue volumen de contraste administrado. Los secundarios, que evaluaron el rendimiento del cateterismo, incluyeron: espasmo radial, tiempo de fluoroscopia y de procedimiento. Resultados: Se incluyeron cinco ensayos, totalizando 1,599 pacientes (802 con estrategia de un catéter y 797 con estrategia de dos catéteres). La estrategia de catéter único requirió menos contraste (diferencia-de-medias; $-3.831 \mathrm{~mL}$ [-6.165 mL $a-1.496 \mathrm{~mL}$ ], $p=0.001$ ), presentando menos espasmo radial (odds ratio, 0.484 [0.363 a 0.644], $p<0.001$ ) y menos tiempo de procedimiento (diferencia-de-medias; -72.471 s [-99.694 s a -45.249 s], $p<0.001$ ). No hubo diferencias en el tiempo de fluoroscopia. Conclusiones: La estrategia de catéter único induce una reducción mínima en la administración de contraste, pero mejora el rendimiento del cateterismo al reducir el espasmo radial y el tiempo de procedimiento en comparación con la estrategia convencional.

Palabras clave: Angiografía coronaria. Estrategia de catéter único. Espasmo radial. Contraste yodado. Revisión sistemática. Meta-análisis.

\section{Introduction}

Coronary angiography is the "gold standard" technique for the diagnosis of coronary atherosclerosis. At present, the access of choice for coronary angiography is transradial access ${ }^{1,2}$. Despite the progressive reduction in coronary procedural complications that have occurred over time, the existence of complications persists and can generate serious consequences ${ }^{1,2}$. The administration of radiological contrast may lead to the development of adverse events such as contrast-induced nephropathy (CIN) or allergic reactions $^{3-5}$. Furthermore, the induction of radial spasm is related with cross-over to transfemoral access and further vascular complications ${ }^{6,7}$. Traditional technique for coronary angiography, by transradial access, uses independent catheters for the cannulation of each coronary artery, inducing radial spasm and requiring additional fluoroscopy time and contrast injections for the correct engage of coronary ostia. Nevertheless, the performance of a coronary angiography with a one-catheter strategy by multipurpose coronary catheters, like TIGER catheters, could simplify procedures decreasing radial spasm, procedural time, and radiological contrast consumption, and currently, it is the usual practice to perform trans-radial coronary angiographies.
In recent years, multiple studies have been published about the benefits of the one-catheter strategy, highlighting greater benefit in observational studies ${ }^{8-11}$ than in controlled studies ${ }^{12-16}$, which may entail a bias in the perception of the real benefits of this strategy, especially regarding radiological contrast saving. However, to date there are no studies that integrate the information derived from randomized clinical trials (RCT) to adequately quantify the advantages of the one-catheter strategy.

Therefore, we performed the first systematic review and meta-analysis of RCT evaluating one-catheter strategy versus two-catheter strategy to compare the amount of iodinated contrast, the induction of radial spasm and fluoroscopy and procedural time, between these two strategies for coronary angiography by transradial access.

\section{Methods}

\section{Search strategy, endpoints, and data extraction}

Two reviewers (DFR and JCM) independently searched PubMed, CINALH, and CENTRAL databases until November 2017. To be included, published studies should be randomized comparisons between one- and 


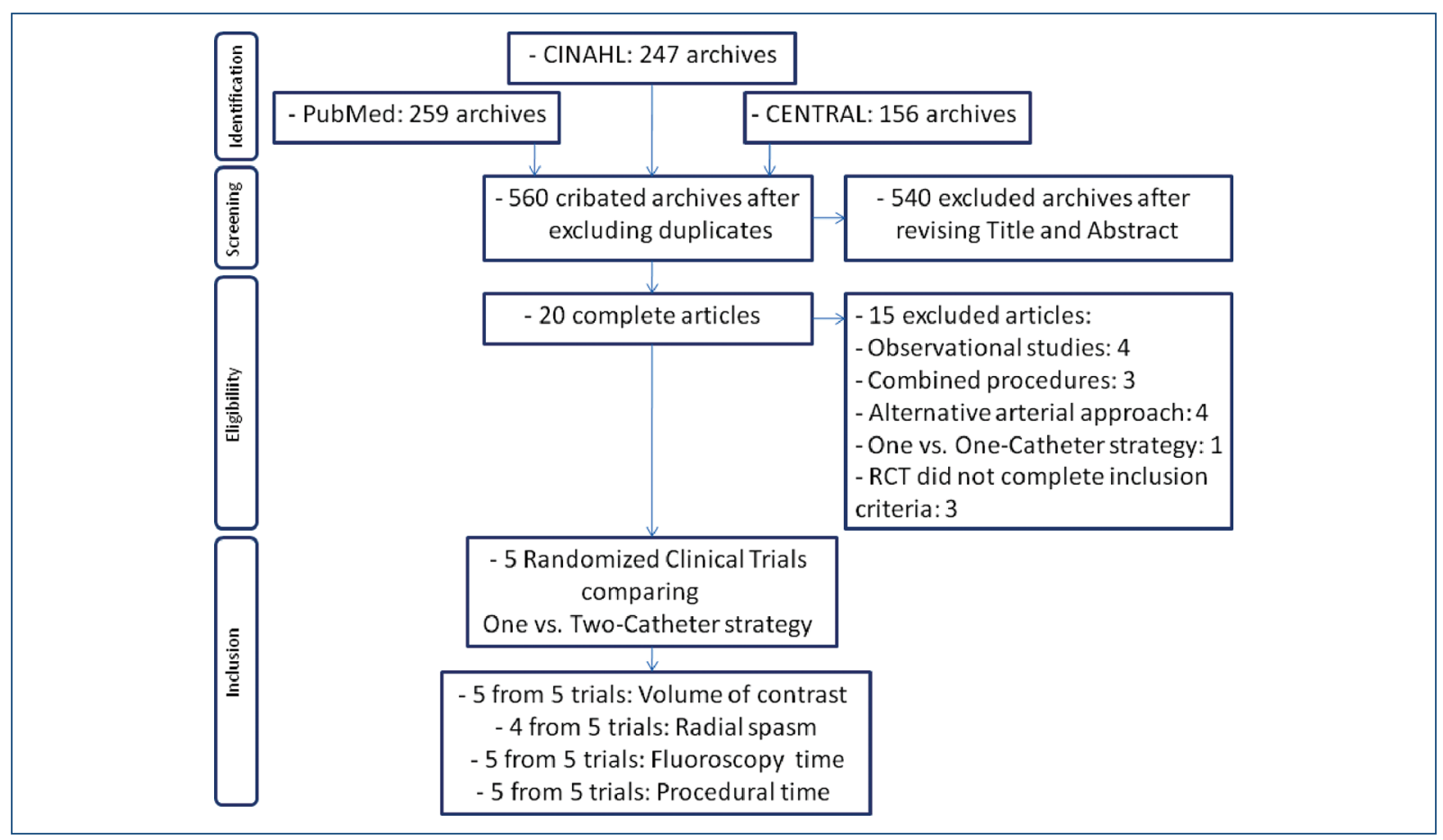

Figure 1. Flow-chart representing bibliographic search and identification of primary studies.

two-catheter strategies for diagnostic coronary angiography. Furthermore, articles had to report on the primary endpoint of our investigation and should be written in English language. The following terms or keywords were used: (one-catheter odds ratio [OR] single catheter OR TIGER catheter OR multipurpose catheter) AND (coronary angiography OR cardiac angiography) AND (controlled study OR randomized study OR RCT). Reference lists of included studies were scanned to retrieve additional relevant studies.

Primary endpoint was total volume of contrast administrated in coronary procedures. Secondary endpoints, evaluating coronary catheterization performance, included radial spasm (definitions according to each study in the Supplementary Material: Table 1), fluoroscopy time, and total procedural time.

RCT were selected if included information about volume of iodinated contrast and the following items were extracted from each selected article: year of publication, type of study design, type of catheter used, number of operators, sample size, total volume of contrast $(\mathrm{mL})$, presence of radial spasm, fluoroscopy time (sec), total procedural time (sec), and baseline clinical characteristics. The authors of the original studies were not required to expand the information referred to such works. Disagreements regarding inclusion or exclusion criteria were resolved by consensus (Fig. 1).

\section{Statistical analysis}

These systematic review and meta-analysis were conducted in accordance with the criteria reported in the Preferred Reporting Items for Systematic Reviews and Meta-Analyses (PRISMA) consensus document (PRISMA) ${ }^{17}$.

Statistical analysis and forest-plot diagrams were performed using the Comprehensive Meta-Analysis software (Biostat, Englewood, NJ, USA). Pooled difference in means (DiM) or OR were used as summary statistics. All p-values were two-tailed, with statistical significance set at 0.05 . The results were presented with a $95 \%$ confidence interval $(95 \% \mathrm{Cl})$. The authors assessed statistical heterogeneity using the $\mathrm{I}^{2}$ test. A fixed-effect model was used in absence of heterogeneity, and a random-effects model was used in case of detecting heterogeneity between studies $\left(\mathrm{I}^{2}\right.$ statistic > $50 \%$ ). Therefore, a fixed-effect model was used for the radial spasm and a random-effects model for the other endpoints. Sensitivity analyses for primary endpoint were conducted excluding one trial at a time. 


\section{Assessment of study quality and publication bias}

Two authors (JC and KR) evaluated the selected RCT studies to assess their quality and possible biases, and in case of discrepancies, they were resolved by consensus. The quality and possible biases of RCT were evaluated using the validated criteria of Juni ${ }^{18}$. For the primary endpoint (volume of contrast administered), the publication bias was assessed using the Egger's statistical test for publication bias and visual inspection of the funnel plot $^{19}$.

\section{Results}

In the literature review, a total of 670 articles were obtained. After reviewing all the titles and abstracts, 20 full-text articles were selected. Fifteen articles, from the total of selected articles, were excluded for the following reasons: four of them were observational studies, three articles informed about guiding catheters designed for combined procedures (diagnostic and therapeutic interventions), four papers were related with alternative arterial approaches to trans-radial access, and one article compared two types of universal dedicated catheters for right trans-radial approach in a one versus one-catheter strategy. It is noteworthy that three RCT comparing one versus two-catheter strategy were not included for the final analysis because one article did not inform about the primary endpoint of the study (volume of contrast administered) ${ }^{20}$ and two articles were not written in English language ${ }^{21,22}$ (Fig. 1). Finally, five studies met the inclusion criteria ${ }^{12-16}$.

These five RCT contained data on 1599 patients. Eight-hundred two patients underwent to one-catheter strategy and 797 patients to two-catheter strategy. Tables 1 and 2 depict main characteristics of the studies. Quality of studies was also evaluated (Table 3).

Regarding to the total volume of contrast used, all five studies ${ }^{12-16}$ were used for the pooled analysis. A significant difference was observed in the total volume of contrast administered favorable to one-catheter strategy (DiM [95\% Cl]; -3.831 mL [-6.165 mL--1.496 mL], $p=0.001)$. A random-effects model was used because the presence of significant heterogeneity $\left(\mathrm{I}^{2}\right.$ test $=$ 59.1\%) (Fig. 2). Publication bias was not detected based on visual inspection of the funnel plot and Egger's regression test for small study effect. Volume of contrast comparison is provided as an example which showed symmetrical funnel plot (Supplementary Fig.1) and $p=$ 0.35 for Egger's test. The sensitivity analysis by

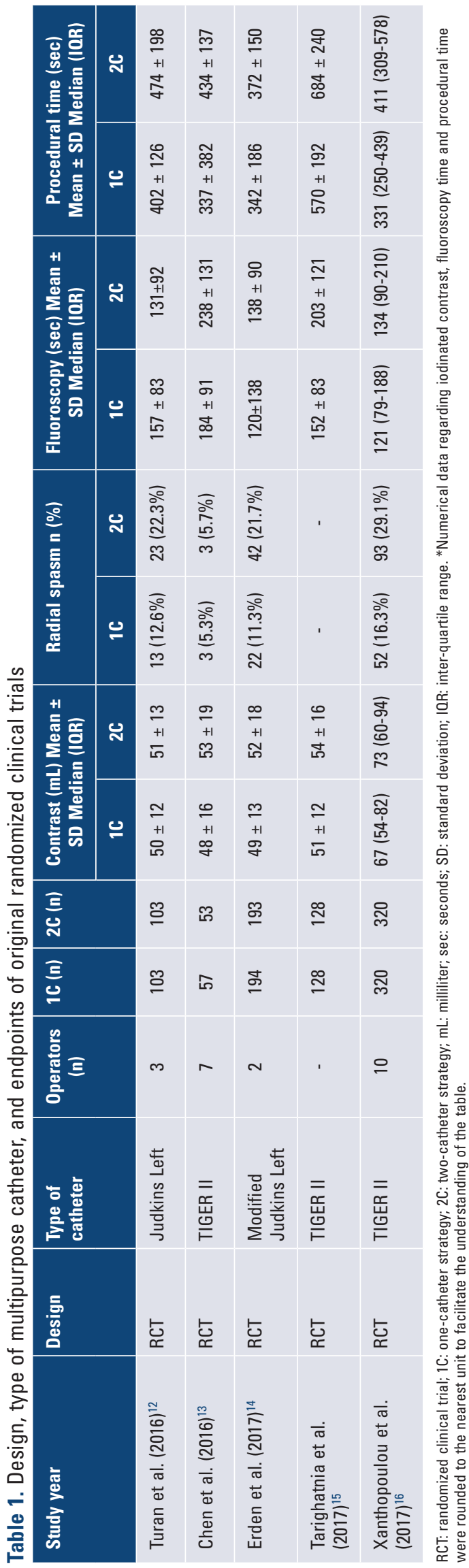




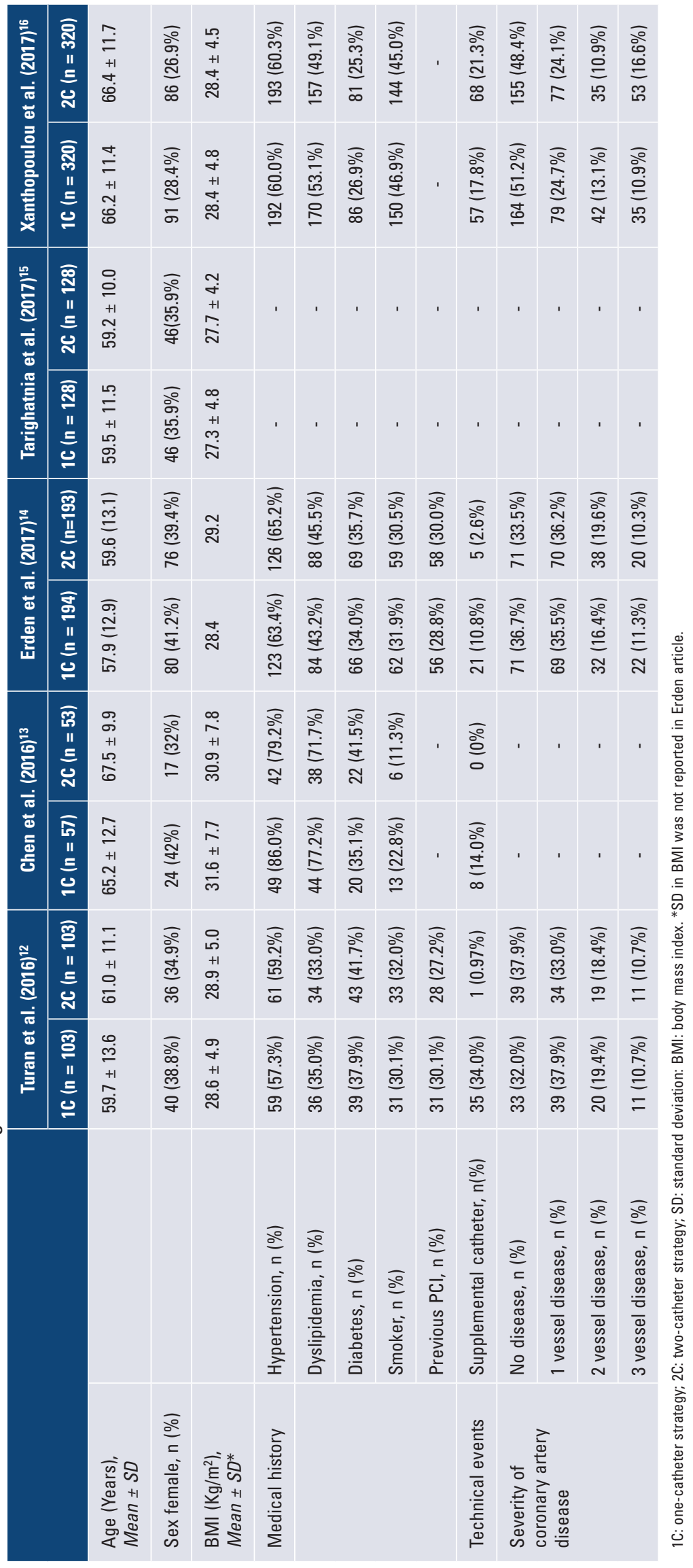


Table 3. Quality assessment for randomized clinical trials included in the systematic review (Juni Criteria)

\begin{tabular}{|c|c|c|c|c|c|}
\hline Studies & $\begin{array}{l}\text { Turan et } \\
\text { al. }(2016)^{12}\end{array}$ & $\begin{array}{l}\text { Chen } \\
\text { et al. }(2016)^{13}\end{array}$ & $\begin{array}{l}\text { Erden } \\
\text { et al. }(2017)^{14}\end{array}$ & $\begin{array}{l}\text { Tarighatnia } \\
\text { et al. }(2017)^{15}\end{array}$ & $\begin{array}{l}\text { Xanthopoulou } \\
\text { et al. (2017) }\end{array}$ \\
\hline \multicolumn{6}{|c|}{ Selection } \\
\hline $\begin{array}{l}\text { 1. Was allocation adequate? Mean-central site, numeric } \\
\text { code, opaque envelopes, drugs prepared by pharmacy }\end{array}$ & Yes & Yes & Yes & Yes & Yes \\
\hline $\begin{array}{l}\text { 2. Was an adequate method of randomization } \\
\text { described? }\end{array}$ & Yes & Yes & Yes & Yes & Yes \\
\hline 3. Were groups similar at the start of the study? & Yes & Yes & Yes & Yes & Yes \\
\hline \multicolumn{6}{|c|}{ Performance } \\
\hline $\begin{array}{l}\text { 4. Were the patients/caregivers blinded to the } \\
\text { intervention? }\end{array}$ & No & No & No & No & No \\
\hline \multicolumn{6}{|c|}{ Detection } \\
\hline 5. Was the outcome ascertained blindly? & Yes & Yes & Yes & Yes & Yes \\
\hline \multicolumn{6}{|c|}{ Attrition } \\
\hline 6. What percentage was lost at follow-up? & $0 \%$ & $0 \%$ & $0 \%$ & $0 \%$ & $0 \%$ \\
\hline $\begin{array}{l}\text { 7. Were all patients analyzed in the group to which } \\
\text { they were assigned (intention-to-treat analysis)? }\end{array}$ & No & Yes & No & Yes & Yes \\
\hline
\end{tabular}

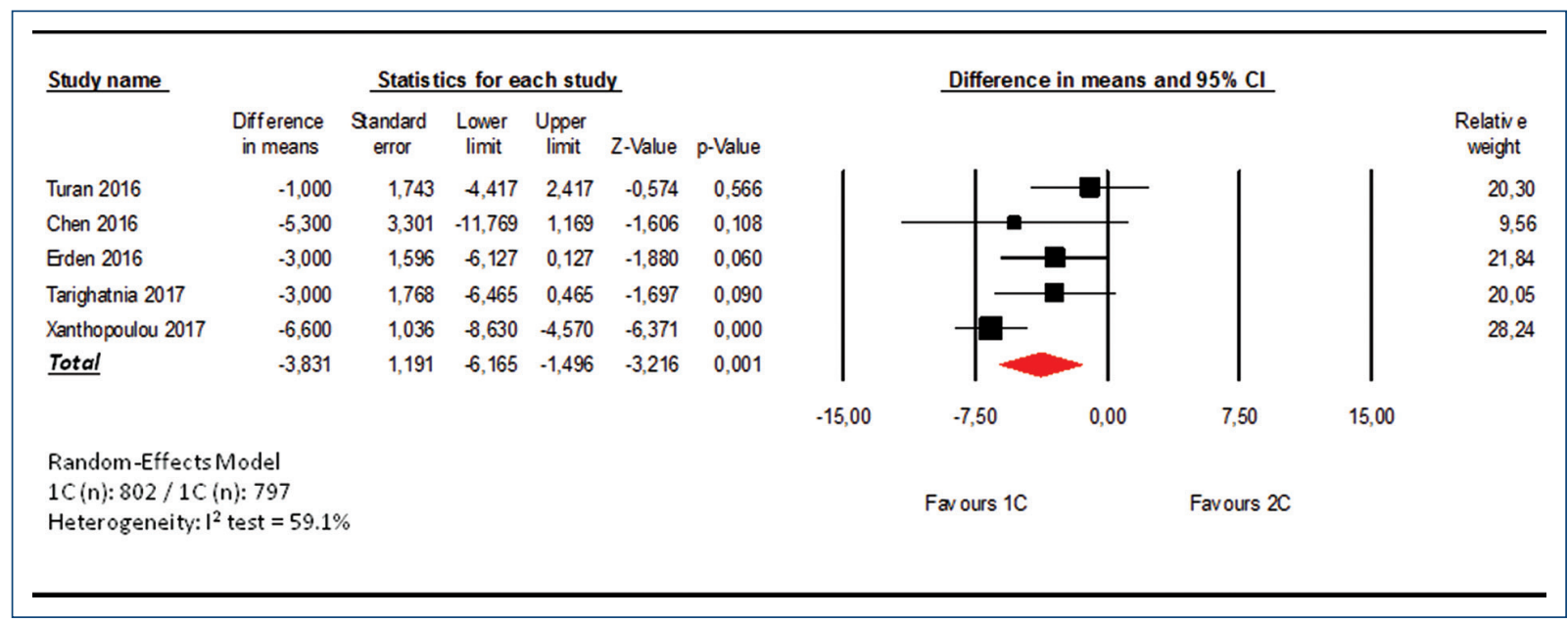

Figure 2. Forest-plot representing volume of contrast administrated. mL: Milliliters. Cl: Confidence interval. $1 \mathrm{C}$ : 0 necatheter strategy. 2C: Two-catheter strategy.

excluding one study at a time did not change direction of the pooled effect sizes.

Four controlled trials ${ }^{12-14,16}$ informed regarding radial spasm, including 674 patients in the $1 \mathrm{C}$ group and 669 patients in the $2 \mathrm{C}$ group. $1 \mathrm{C}$ group presented less induction of radial spasm (OR [95\% Cl]; 0.484 [0.363-0.644], $\mathrm{p}<0.001)$. A fixed-effects model was used because the absence of heterogeneity $\left(I^{2}\right.$ test $=0.0 \%$ ) (Fig. 3).

In the analysis related to fluoroscopy time, all five $\mathrm{RCT}^{12-16}$ were included for the analysis. No differences were detected on fluoroscopy time was detected between groups (DiM [95\% Cl], $-19.193 \mathrm{~s}[-41.425 \mathrm{~s}$ to $-3.039 \mathrm{~s}], p=0.091)$. It is noteworthy that a random effects model was performed to the significant heterogeneity $\left(\mathrm{I}^{2}\right.$ test $=82.3 \%$ ) (Fig. 4).

All five randomized trials ${ }^{12-16}$ informed regarding the total procedural time. A significant difference was observed (DiM [95\% Cl], -72.471 s [-99.694 s to-45.249 s], $p<0.001$ ). Because the heterogeneity, a random effects method was used $\left(l^{2}\right.$ test $\left.=58.2 \%\right)($ Fig. 5). 


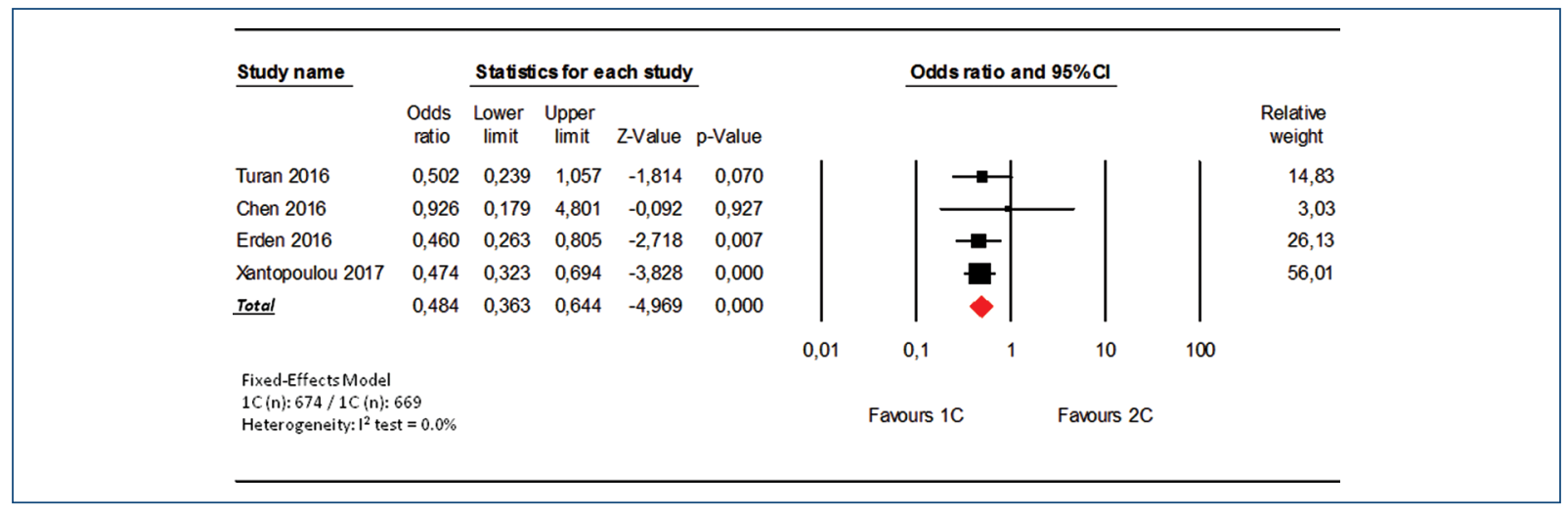

Figure 3. Forest-plot representing radial spasm. CI: Confidence interval. 1C: One-catheter strategy. 2C: Two-catheter strategy.

\begin{tabular}{|c|c|c|c|c|c|c|c|c|c|c|c|c|}
\hline \multirow[t]{2}{*}{ Study name } & \multirow[b]{2}{*}{$\begin{array}{l}\text { Diff erence } \\
\text { in means }\end{array}$} & \multicolumn{5}{|c|}{ Statis tics for each study } & & \multicolumn{4}{|c|}{ Difference in means and $95 \% \mathrm{Cl}$} & \multirow[b]{2}{*}{$\begin{array}{c}\text { Relative } \\
\text { weight }\end{array}$} \\
\hline & & $\begin{array}{l}\text { Sandard } \\
\text { error }\end{array}$ & $\begin{array}{l}\text { Lower } \\
\text { limit }\end{array}$ & $\begin{array}{l}\text { Upper } \\
\text { limit }\end{array}$ & Z-Value & p-Value & & & & & & \\
\hline Turan 2016 & 26,000 & 12,209 & 2,071 & 49,929 & 2,130 & 0,033 & & & & H & 1 & 20,27 \\
\hline Chen 2016 & $-54,000$ & 21,382 & $-95,909$ & $-12,091$ & $-2,525$ & 0,012 & & & & & & 13,64 \\
\hline Eden 2016 & $-18,000$ & 11,850 & $-41,226$ & 5,226 & $-1,519$ & 0,129 & & & - & & & 20,55 \\
\hline Tarighatnia 2017 & $-51,000$ & 12,969 & $-76,419$ & $-25,581$ & $-3,932$ & 0,000 & & & & & & 19,67 \\
\hline Xanthopoulou 2017 & $-13,000$ & 3,400 & $-19,665$ & $-6,335$ & $-3,823$ & 0,000 & & & & & & 25,87 \\
\hline \multirow[t]{2}{*}{ Total } & $-19,193$ & 11,343 & $-41,425$ & 3,039 & $-1,692$ & 0,091 & & & & & & \\
\hline & & & & & & & $-100,00$ & $-50,00$ & 0,00 & 50,00 & 100,00 & \\
\hline \multicolumn{13}{|c|}{ Random-EffectsModel } \\
\hline \multicolumn{2}{|c|}{$1 C(n): 802 / 1 C(n): 797$} & & & & & & & Fav ours $1 \mathrm{C}$ & & Favours $2 \mathrm{C}$ & & \\
\hline
\end{tabular}

Figure 4. Forest-plot representing fluoroscopy time. sec: Seconds. Cl: Confidence interval. 1C: One-catheter strategy. 2C: Two-catheter strategy.

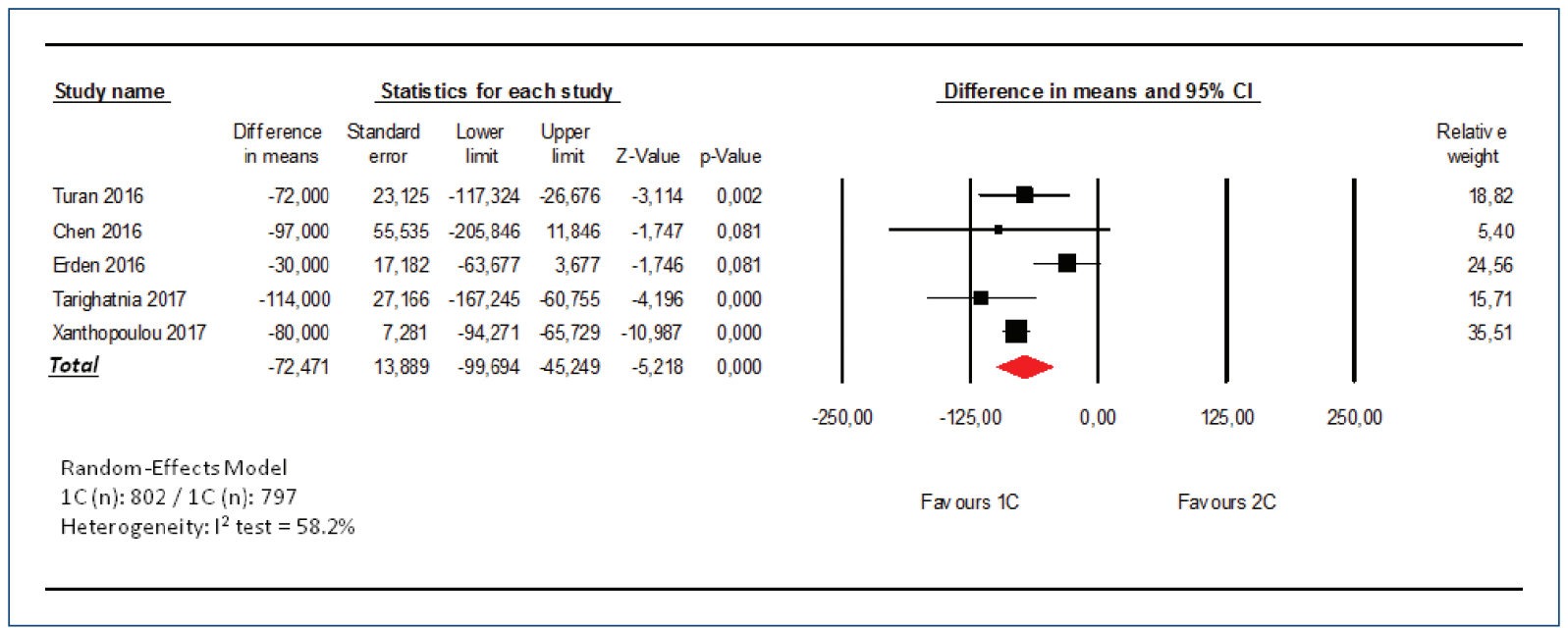

Figure 5. Forest-plot representing procedural time. Sec: Seconds. Cl: Confidence interval. 1C: One-catheter strategy. 2C: Two-catheter strategy. 


\section{Discussion}

The main findings in our investigation were that of one-catheter strategy is associated with a minimal reduction in the volume of iodinated contrast used in coronary angiography procedures and a better performance in diagnostic coronary catheterization, evaluated as radial spasm and procedural time, in comparison with conventional two-catheter strategy.

\section{Radiological contrast administration}

One of main complications of invasive coronary procedures is the development of CIN. This condition could reach one-third of patients undergoing coronary procedures and is one of the more common causes of acute kidney injury in cardiological patients ${ }^{3,4,23,24}$. Furthermore, CIN is related with prolongation of the hospitalization, the death at short- and long-term ${ }^{3,4}$ and increments in direct and indirect costs ${ }^{25}$. Because of the amount of iodinated contrast used in angiographic procedures is closely linked to $\mathrm{CIN}^{26,27}$, the implementation of any technique that could reduce the administration of radiological contrast is very much appreciated by interventional cardiologists.

Pooled results show a consistent reduction in the primary endpoint of the study (volume of radiological contrast used in coronary diagnostic procedures). Nevertheless, the reduction in contrast administration is minimal in the joint analysis of RCT (DiM $[95 \% \mathrm{Cl}$; $-3.831 \mathrm{~mL}$ [-6.165 mL--1.496 mL], $p=0.001$ ). A recent observational study with a large number of patients observed a reduction in contrast administration, by one-catheter strategy, reaching $20 \mathrm{~mL}$ of radiological contrast $^{28}$. However, the study of Langer et al. ${ }^{28}$ could perhaps overestimate the effect of the one-catheter strategy on contrast saving, since it was an observational and retrospective study. This could also be motivated because in the participating centers, the standard catheter for performing coronary angiography in the usual clinical practice was the Tiger multipurpose catheter and the two-catheter strategy was used less frequently and this fact could penalize the two-catheter strategy.

The main finding of our study, which only analyzes randomized studies, is that the amount of contrast saved by the one-catheter strategy is very small. This fact implies that the preference of the one-catheter strategy over the two-catheter strategy at the time of performing coronary procedures would not be mediated by the supposed saving of radiological contrast but by other aspects related to the catheterization performance as we explain below.

\section{Coronary catheterization performance}

Radial spasm is a relatively common complication on transradial access with a variable incidence, ranging from $5 \%$ to $30 \%$, depending on the definition ${ }^{29-33}$. Radial spasm induces patient discomfort and reduces procedural success ${ }^{29,30}$. In cases with need for conversion to transfemoral access is related with an increase in vascular complications ${ }^{1,34}$.

Many factors, such as age, female gender, multiple radial punctures, and radial diameter are related with radial spasm. ${ }^{6,7,30-32}$. Furthermore, exchange of catheters during by transradial access has been linked to radial spasm induction, probably in relation to the repeated stimulation of the radial artery ${ }^{6}$. Likewise, the prolonged duration of coronary procedures may favor the development of arterial spasm and reduces patient comfort in trans-radial procedures, associating with greater probability of complications $\mathrm{s}^{6,7,30-32}$.

Our results show an important reduction in radial spasm (OR [95\% Cl], 0.484 [0.363-0.644], p < 0.001). Furthermore, one-catheter strategy produces a small reduction in procedural time (DiM $[95 \% \mathrm{Cl}],-72.471 \mathrm{~s}$ [-99.694 s--45.249 s], p < 0.001) in comparison with conventional strategy, but no significant differences between groups were detected on fluoroscopy time despite the favorable trend to one-catheter strategy (DiM [95\% Cl], $-19.193 \mathrm{~s}$ [-41.425 s to $-3.039 \mathrm{~s}], \mathrm{p}=0.091$ ).

These facts make us hypothesize that one-catheter strategy, by reducing radial spasm development, simplifies the manipulation of coronary catheters resulting in slightly shorter times to complete diagnostic procedures and could decrease potential complications associated with radial spasm.

\section{Limitations}

The present study is limited by the presence of heterogeneity for some of the outcomes, which can be explained in part by the variation in the study design. However, random-effects models were used to mitigate this limitation if heterogeneity was detected. Due to lack of access to primary data, analyses based on patient characteristics regarding primary and secondary endpoints could not be performed. Nevertheless, our work is the first one performing a pooled analysis of RCT evaluating one-catheter strategy for diagnostic 
coronary angiography which ensures the high quality of the studies included in the combined analysis.

Furthermore, individual studies included were not blinded to operators. This fact could influence operators regarding technical aspects like the final number of angiographical views, the fluoroscopy time or the total amount of contrast used. However, because the studies were protocolized randomized trials, the chances that the lack of blinding of the studies could affect the results are minimized.

\section{Conclusions}

One-catheter strategy for trans-radial coronary angiography induces only a minimal reduction on radiological contrast administration. Nevertheless, one-catheter strategy improves coronary catheterization performance, by reducing arterial spasm, and procedural time, as compared to two-catheter strategy.

\section{Conflicts of interest}

None.

\section{Ethical disclosures}

Protection of human and animal subjects. The authors declare that no experiments were performed on humans or animals for this study.

Confidentiality of data. The authors declare that they have followed the protocols of their work center on the publication of patient data.

Right to privacy and informed consent. The authors declare that no patient data appear in this article.

\section{References}

1. Windecker S, Kolh P, Alfonso F, Collet JP, Cremer J, Falk V, et al. 2014 ESC/EACTS guidelines on myocardial revascularization: the task force on myocardial revascularization of the European society of cardiology (ESC) and the European association for cardio-thoracic surgery (EACTS) developed with the special contribution of the European association of percutaneous cardiovascular interventions (EAPCI). Eur Heart J. 2014;35:2541-619.

2. Ibanez B, James S, Agewall S, Antunes MJ, Bucciarelli-Ducci C, Bueno $\mathrm{H}$, et al. $2017 \mathrm{ESC}$ guidelines for the management of acute myocardial infarction in patients presenting with ST-segment elevation: the task force for the management of acute myocardial infarction in patients presenting with ST-segment elevation of the European society of cardiology (ESC). Eur Heart J. 2017;39:119-77.

3. McCullough PA, Wolyn R, Rocher LL, Levin RN, O'Neill WW. Acute renal failure after coronary intervention: incidence, risk factors, and relationship to mortality. Am J Med. 1997; 103:368-75.

4. Rihal CS, Textor SC, Grill DE, Berger PB, Ting HH, Best PJ, et al. Incidence and prognostic importance of acute renal failure after percutaneous coronary intervention. Circulation. 2002;105:2259-64.

5. Brockow K, Ring J. Anaphylaxis to radiographic contrast media. Curr Opin Allergy Clin Immunol. 2011;11:326-31.
6. Trilla $M$, Freixa $X$, Regueiro A, Fernández-Rodriguez D, Brugaletta $S$, Martin-Yuste $V$, et al. Impact of aging on radial spasm during coronary catheterization. J Invasive Cardiol. 2015;27:E303-7.

7. Kristic I, Lukenda J. Radial artery spasm during transradial coronary procedures. J Invasive Cardiol. 2011;23:527-31.

8. Sanmartin M, Esparza J, Moxica J, Baz JA, Iñiguez-Romo A. Safety and efficacy of a multipurpose coronary angiography strategy using the transradial technique. J Invasive Cardiol. 2005;17:594-7.

9. Vorpahl M, Koehler T, Foerst J, Panagiotopoulos S, Schleiting H, Koss K, et al. Single center retrospective analysis of conventional and radial TIG catheters for transradial diagnostic coronary angiography. Cardiol Res Pract. 2015;2015:862156.

10. Plourde G, Abdelaal E, MacHaalany J, Rimac G, Poirier Y, Arsenault J, et al. Comparison of radiation exposure during transradial diagnostic coronary angiography with single-or multi-catheters approach. Catheter Cardiovasc Interv. 2017; $90: 243-248$.

11. Langer C, Riehle J, Frey N, Wiemer M. Transradial coronary angiography--insights to the one-catheter concept. J Interv Cardiol. 2016;29: 113-6.

12. Turan B, Erkol A, Mutlu A, Daşli T, Erden İ. Effectiveness of left Judkins catheter as a single multipurpose catheter in transradial coronary angiography from right radial artery: a randomized comparison with conventional two-catheter strategy. J Interv Cardiol. 2016;29:257-64.

13. Chen O, Goel S, Acholonu M, Kulbak G, Verma S, Travlos E, et al. Comparison of standard catheters versus radial artery-specific catheter in patients who underwent coronary angiography through transradial access. Am J Cardiol. 2016;118:357-61.

14. Erden I, Golcuk E, Bozyel S, Erden EC, Balaban Y, Yalın K, et al. Effectiveness of handmade Jacky-like catheter as a single multipurpose catheter in transradial coronary angiography: a randomized comparison with conventional two-catheter strategy. J Interv Cardiol. 2017;30:24-32.

15. Tarighatnia A, Pourafkari L, Farajollahi A, Mohammadalian AH, Ghojazadeh M, Nader ND. Operator radiation exposure during transradial coronary angiography: effect of single vs. double catheters. Herz. 201743:535-42.

16. Xanthopoulou I, Stavrou K, Davlouros P, Tsigkas G, Koufou E, Almpanis $\mathrm{G}$, et al. Randomized comparison of JUDkins vs tiGEr catheter in coronary angiography via the right radial artery: the JUDGE study. Eurointervention. 2017;13:1950-8.

17. Moher D, Liberati A, Tetzlaff J, Altman DG. Preferred reporting items for systematic reviews and meta-analyses: the PRISMA statement. BMJ. 2009;339:b2535.

18. Jüni $P$, Altman DG, Egger M. Systematic reviews in health care: assessing the quality of controlled clinical trials. BMJ. 2001;323:42-6.

19. Egger M, Davey Smith G, Schneider M, Minder C. Bias in meta-analysis detected by a simple, graphical test. BMJ. 1997;315:629-34.

20. Kim SM, Kim DK, Kim DI, Kim DS, Joo SJ, Lee JW. Novel diagnostic catheter specifically designed for both coronary arteries via the right transradial approach. A prospective, randomized trial of Tiger II vs. Judkins catheters. Int J Cardiovasc Imaging. 2006;22:295-303.

21. Cho YC, Kim W, Ban JS, Kim JT, No MJ, Jeong AD, et al. The clinical usefulness of a tiger catheter in diagnostic coronary angiography via the transradial approach. Korean Circ J. 2009;39:11-5.

22. Park EH, Kim MH, Park TH, Ahn SJ, Jung DS, Paik JH, et al. Feasibility of transradial coronary angiography using a single Judkins left catheter. Korean Circulation J. 2005;35:253-7.

23. Parfrey PS, Griffiths SM, Barrett BJ, Paul MD, Genge M, Withers J, et al. Contrast material-induced renal failure in patients with diabetes mellitus, renal insufficiency, or both: a prospective controlled study. N Engl J Med. 1989;320:143-9.

24. Gruberg L, Mintz GS, Mehran R, Gangas G, Lansky AJ, Kent KM, et al. The prognostic implications of further renal function deterioration within $48 \mathrm{~h}$ of interventional coronary procedures in patients with pre-existent chronic renal insufficiency. J Am Coll Cardiol. 2000;36:1542-8.

25. Hou SH, Bushinsky DA, Wish JB, Cohen JJ, Harrington JT. Hospital acquired renal insufficiency: a prospective study. Am J Med. 1983;74:243-8.

26. Raposeiras-Roubín S, Abu-Assi E, Ocaranza-Sánchez R, Alvarez-Álvarez B, Cambeiro-González C, Fandiño-Vaquero $\mathrm{R}$, et al. Dosing of iodinated contrast volume: a new simple algorithm to stratify the risk of contrast-induced nephropathy in patients with acute coronary syndrome. Catheter Cardiovasc Interv. 2013;82:888-97

27. Cigarroa RG, Lange RA, Williams RH, Hillis LD. Dosing of contrast material to prevent contrast nephropathy in patients with renal disease. Am J Med. 1989;86:649-52.

28. Langer $C$, Riehle J, Wuttig $H$, Dürrwald $S$, Lange $H$, Samol A, et al Efficacy of a one-catheter concept for transradial coronary angiography. PLoS One. 2018;13:e0189899. 
29. Bertrand OF, Rao SV, Pancholy S, Jolly SS, Rodés-Cabau J, Larose E, et al. Transradial approach for coronary angiography and interventions: results of the first international transradial practice survey. JACC Cardiovasc Interv. 2010;3:1022-31.

30. Kiemeneij F, Vajifdar BU, Eccleshall SC, Laarman G, Slagboom T, van der Wieken R. Evaluation of a spasmolytic cocktail to prevent radial artery spasm during coronary procedures. Catheter Cardiovasc Interv. 2003:58:281-4.

31. Abdelaal E, Brousseau-Provencher C, Montminy S, Plourde G, MacHaalany J, Bataille $Y$, et al. Risk score, causes, and clinical impact of failure of transradial approach for percutaneous coronary interventions. JACC Cardiovasc Interv. 2013;6:1129-37.
32. Jia DA, Zhou YJ, Shi DM, Liu YY, Wang JL, Liu XL, et al. Incidence and predictors of radial artery spasm during transradial coronary angiography and intervention. Chin Med J. 2010;123:843-7.

33. Gorgulu S, Norgaz T, Karaahmet T, Dagdelen S. Incidence and predictors of radial artery spasm at the beginning of a transradial coronary procedure. J Interv Cardiol. 2013;26:208-13.

34. Sanmartin M, Cuevas D, Goicolea J, Ruiz-Salmeron R, Gomez M, Argibay V. Vascular complications associated with radial artery access for cardiac catheterization. Rev Esp Cardiol. 2004;57:581-4. 


\section{Comparison of one-catheter strategy versus conventional two-catheter strategy on the volume of radiological contrast and diagnostic coronary catheterization performance by transradial access: A systematic review and meta-analysis of randomized clinical trials}

Comparación de la estrategia de catéter único versus la estrategia convencional de dos catéteres sobre el volumen de contraste radiológico y el rendimiento del cateterismo coronario diagnóstico por acceso transradial: una revisión sistemática y meta-análisis de ensayos clínicos aleatorizados

Diego Fernández-Rodríguez*, Joan Costa-Mateu, Kristian Rivera, Juan Casanova, Anna Bosch-Gaya, Carlos Tomás-Querol, Marta Zielonka, Eduardo Pereyra-Acha, Lucía Matute-Blanco, and

Fernando Worner

Department of Cardiology, University Hospital Arnau de Vilanova, Institut de Recerca Biomédica de Lleida, University of Lleida, Lleida, Spain

\section{Supplementary material}

Table 1. Radial artery spasm definitions in original randomized clinical trials

\begin{tabular}{|c|c|}
\hline Study/Year & Radial artery spasm definitions \\
\hline Turan et al. $(2016)^{12}$ & $\begin{array}{l}\text { Identification of radial artery spasm by arteriography or marked resistance to catheter movements } \\
\text { associated with moderate-to-severe forearm pain }\end{array}$ \\
\hline Chen et al. $(2016)^{13}$ & $\begin{array}{l}\text { Need to access site switch from radial to femoral to complete the coronary angiography related with } \\
\text { radial artery spasm. }\end{array}$ \\
\hline Erden et al. $(2017)^{14}$ & $\begin{array}{l}\text { Identification of radial artery spasm by arteriography or marked resistance to catheter movements } \\
\text { associated with moderate-to-severe forearm pain }\end{array}$ \\
\hline Tarighatnia et al. $(2017)^{15}$ & Not evaluated \\
\hline Xanthopoulou et al. $(2017)^{16}$ & $\begin{array}{l}\text { Radial artery spasm was graded as: } \\
\text { - Mild: Radial spasm causing well tolerated local pain } \\
\text { - Moderate: Radial spasm causing severe pain but the handling of catheters remains satisfactory } \\
\text { - Severe: Radial spasm causing catheter failure that leads to catheter change and/or access site } \\
\text { change for completion of coronary angiography. } \\
\text { *For the purpose of our investigation, any grade of radial artery spasm was included for the meta- } \\
\text { analysis. }\end{array}$ \\
\hline
\end{tabular}

Correspondence:

*Diego Fernández-Rodríguez

E-mail: d.fernan.2@ hotmail.com
Date of reception: 01-10-2019

Date of acceptance: 30-06-2020

DOI: 10.24875/ACM.19000352
Available online: $23-12-2020$ Arch Cardiol Mex. 2020;90(4):1-2

www.archivoscardiologia.com 1405-9940 / @ 2020 Instituto Nacional de Cardiología Ignacio Chávez. Published by Permanyer. This is an open access article under the CC BY-NC-ND license (http://creativecommons.org/licenses/by-nc-nd/4.0/). 


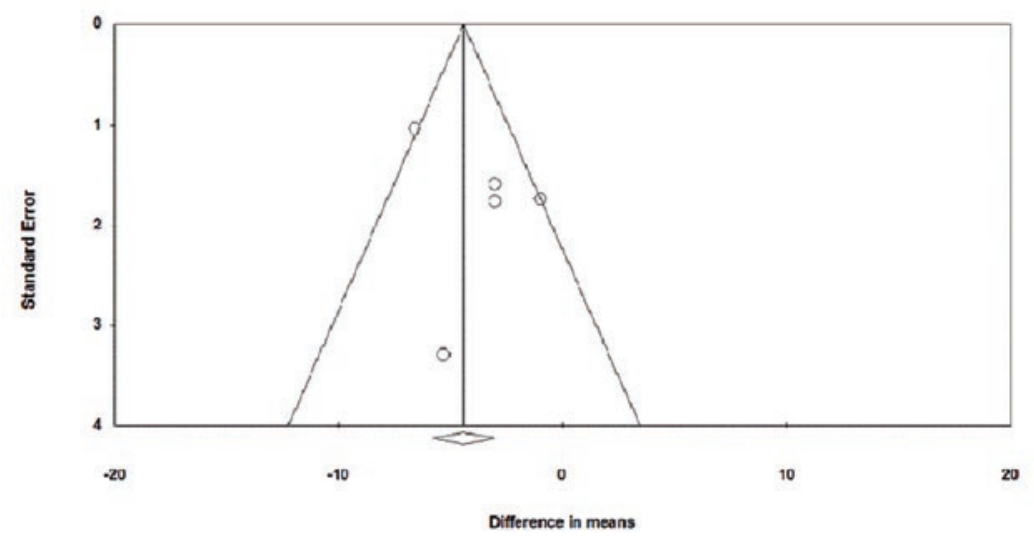

Supplementary Figure 1. Assessment of publication bias. Funnel plot for primary endpoint (Volume of contrast) presenting difference in means versus standard error of effect estimate and $95 \% \mathrm{Cl}$ showing the publication bias and the consistency of the result around the mean outcome. Cl: Confidence interval. 